\title{
New molecular evidence on genome relationships and chromosome identification in fescue (Festuca) and ryegrass (Lolium)
}

\author{
I. PAŚAKINSKIENË $† \S$, K. ANAMTHAWAT-JÓNSSON $\ddagger$ M. W. HUMPHREYS $†$, \\ V. PAPLAUSKIENE \& R. N. JONEST \\ $\dagger$ Institute of Grassland and Environmental Research, Plas Gogerddan, Aberystwyth SY23 3EB, U.K., $\$$ University of \\ Iceland, Grensásvegur 12, 108 Reykjavik, Iceland, \$Lithuanian Institute of Agriculture, 5051 Dotnuva-Akademija, \\ Kedainiai, Lithuania, and TUniversity of Wales Aberystwyth, Institute of Biological Sciences, Aberystwyth SY23 3DD, \\ U.K.
}

\begin{abstract}
The level of similarity between the DNA of Lolium multiflorum and three Festuca species, $F$. arundinacea, $F$. pratensis and $F$. glaucescens, was analysed on Southern blots, using DNA-DNA hybridization, and also on chromosomes using genomic in situ hybridization (GISH). It was demonstrated that the close relationship between $L$. multiflorum and the allohexaploid $F$. arundinacea arises principally from the affinity of $L$. multiflorum to one of the ancestral progenitors of $F$. arundinacea, namely $F$. pratensis. Using probes made from total genomic DNA of $L$. multiflorum, and also of $L$. perenne, particular regions of high homology, described here as 'GISH bands' were identified on $F$. pratensis chromosomes. These GISH bands, in combination with a specific probe for rDNA, provide us with new markers for the identification of chromosomes within the $F$. pratensis complement. Restriction analysis within the rDNA repeat unit revealed additional information on the close phylogeny of $L$. multiflorum and $F$. pratensis. The rDNA restriction patterns confirm that $F$. arundinacea originated as a hybrid between $F$. pratensis and $F$. glaucescens.
\end{abstract}

Keywords: GISH bands, Lolium/Festuca, phylogeny, rDNA, restriction analysis.

\section{Introduction}

Species within the Lolium/Festuca complex are closely related, easily hybridized and exhibit promiscuous meiotic recombination (Thomas et al., 1994). The two genera are considered to have diverged from a common ancestor and have a basic chromosome number of $x=7$ (Malik \& Thomas, 1966). Within the range of intergeneric Festulolium hybrids available, L. multiflorum $(\mathrm{Lm})$ and diploid $F$. pratensis $(F p)$, or $L m$ and hexaploid $F$ arundinacea $(F a)$, show especially high compatibility (Buckner et al., 1961; Cremades \& Bean, 1975) and provide a particularly valuable combination of complementary agronomic traits (Thomas \& Humphreys, 1991). Fp and the tetraploid $F$. glaucescens $(F g)$ are the progenitors of the allohexaploid $\mathrm{Fa}\left(\mathrm{FpFpFgFgFg}{ }_{1} \mathrm{Fg}_{1}\right)$ (Humphreys et al., 1995).

Some amphiploid cultivars have been established from crosses of $L m$ and $F p$ tetraploids (Breese \&

*Correspondence. E-mail: genetik@lzi.lt
Lewis, 1984; Zwierzykowski et al., 1994), and these hybrids are valuable because they combine the good forage quality of Lolium with the high stress tolerance of Festuca. A problem of amphiploid breeding is the high level of homoeologous pairing between the different genomes, which leads to genetic instability and loss of hybridity in later generations.

To overcome this 'genotypical deterioration', an alternative strategy, based on introgression breeding, has been developed (Humphreys, 1989). This strategy has now been used successfully to transfer drought resistance from $F a$ into $L m$ using the pentaploid hybrid $\operatorname{Lm}(2 n=4 x=28) \times F a \quad(2 n=$ $6 x=42)$ backcrossed to diploid $\operatorname{Lm}(2 n=2 x=14)$ as the recurrent parent (Humphreys $\&$ Thomas, 1993). GISH was used to follow the physical location of the introgressed segments, and it was demonstrated that these segments originated from the $F p$ genome of the $F a$ parent, and not from $F g$ (Humphreys \& Pašakinskienè, 1996).

It is clear that to maximize the efficiency of such introgression programmes requires the fullest 
possible understanding of genomic relationships among these Lolium and Festuca species, and only then can determine the ideal partners for use in breeding programmes be determined. It is for this reason that GISH studies were undertaken initially. The first investigations were made with probes from genomic DNA of $F p$ in the hybrid cultivars and their derivatives from the cross of $L m \times F p$. These demonstrated that the $F p$ and $L m$ genomes could be distinguished on the basis of their total genomic DNAs (Thomas et al., 1994). In a later study, probes from both $F p$ and $F g$ were used to discriminate and to determine the progenitors of hexaploid $\mathrm{Fa}$ (Humphreys et al., 1995). A $L m$ probe was used for the first time to investigate phenomena associated with chromosome elimination and somatic recombination in octoploid hybrids between $\mathrm{Lm}$ and $\mathrm{Fa}$ ( $\mathrm{Pa}$ šakinskienè et al., 1997).

In the present study, the novel use of a $\mathrm{Lm}$ probe to reveal differences between the $F p$ and $F g$ genomes of $\mathrm{Fa}$ is demonstrated. The $\mathrm{Lm}$ probe, as well as a probe made from $L$. perenne $(L p)$ are used as markers to produce GISH bands that identify some of the individual chromosomes of the $F p$ set. Also included is additional information on genome relationships using the $L m$ probe in Southern DNA-DNA hybridization, and the pTa71 probe for restriction analysis of the rDNA.

\section{Materials and methods}

\section{In situ hybridization}

Root-tip mitotic chromosomes of $F a$ genotype 870 $(2 n=42)$, originating from the Dutch cv. 'Barundi', and of the hybrid between $L p \times F a 870$ were prepared after pretreatment in ice-cold water for $24 \mathrm{~h}$, followed by fixation in 1:3 acetic acid-ethanol. The roots were softened in a mixture of $20 \%$ pectinase and $2 \%$ cellulase, and then squashed in $45 \%$ acetic acid.

In situ hybridization was carried out at the Institute of Grassland and Environmental Research in Aberystwyth, according to the protocol described by Anamthawat-Jónsson \& Heslop-Harrison (1996). To make the probes, total genomic DNAs of $L m, L p$ and $F p$ were sonicated to give fragments of $5-10 \mathrm{~kb}$ and labelled with rhodomine-4-dUTP (Amersham), using the standard protocol for the nick translation system (Gibco BRL). A probe was also made from the rDNA clone pTa71 (Gerlach \& Bedbrook, 1979) by labelling with fluorescein 12-dCTP. Blocking DNA of $200-500 \mathrm{bp}$ fragments from $\mathrm{Fa}$ was prepared by autoclaving for $2 \mathrm{~min}$. The probe hybridization mixture ( $40 \mu \mathrm{L}$ per slide) contained $100 \mathrm{ng}$ of labelled DNA, 4-6 $\mu \mathrm{g}$ of blocking DNA, $50 \%$ formamide in $2 \times \mathrm{SSC}(0.3 \mathrm{~m}$ sodium chloride, $30 \mathrm{~mm}$ trisodium citrate), $10 \%$ dextran sulphate and $0.2 \%$ SDS (lauryl sulphate). The hybridization mixtures were denatured by boiling for $5 \mathrm{~min}$, then placed on ice. The chromosome preparations on the slides were denatured using $70 \%$ formamide in $2 \times \mathrm{SSC}$ at $70^{\circ} \mathrm{C}$ for $2 \mathrm{~min}$, dehydrated in an ice-cold ethanol series $(70 \%, 90 \%$ and $100 \%$ for 2 min each) and allowed to dry. Hybridization mixtures were then applied to the slides and incubated at $37^{\circ} \mathrm{C}$ overnight. Slides were washed with $20 \%$ formamide in $0.1 \times \mathrm{SSC}$ at $42^{\circ} \mathrm{C}$ for $10 \mathrm{~min}$ and then rinsed three times in $2 \times \mathrm{SSC}$. For reprobing with $F p$ genomic DNA, the slide was soaked in $4 \times$ SSC with Tween 20, the coverslip removed, and then washed three times in $2 \times \mathrm{SSC}$. The routine procedure starting with denaturation in $70 \%$ formamide was then carried out as described above. DAPI-stained and antifade-mounted slides were studied with an epifluorescent microscope. Images were photographed on Fujichrome Sensia 400 slide film.

\section{Southern hybridization}

Experiments were carried out at the Icelandic Agricultural Research Institute in Keldnaholt. The plant material comprised $\mathrm{Lm}$ (the Dutch var. Bartissimo), $F a$ (the Polish var. Terros), $F p$ (the Lithuanian var. Dotnuva) and $F g$ (an accession from the Swiss Alps). DNA was extracted from leaf material using the method of Doyle \& Doyle (1990). The nonradioactive chemiluminescent method (ECL; Amersham) was used for probe labelling, and hybridization and detection were carried out according to a modification of the manufacturer's instructions. Total genomic DNA from $L m$ and rDNA from the clone pTa71 were labelled by cross-linking to horseradish peroxidase with glutaraldehyde. $L m$ DNA was denatured by boiling for $5 \mathrm{~min}$ before labelling. The rDNA pTa71 clone was used as a probe $\left(5 \mathrm{ng} \mathrm{cm}^{-2}\right)$ on the Southern blots of total genomic DNAs $(1 \mu \mathrm{g}$ per lane) from $L m, F p, F g$ and $F a$ digested with EcoRI, DraI and BamHI. Lm DNA was used as a probe on the Southern blots of genomic DNAs from Lm (control), Fp, Fg and $F a$ digested with BamHI. The nylon membranes were incubated for 30-60 min at $42^{\circ} \mathrm{C}$ in ECL hybridization buffer containing $6 \mathrm{M}$ urea, with the addition of $0.1 \mathrm{~m}$ sodium chloride for the $L m$ probe or $0.5 \mathrm{M}$ for the pTa71 probe. Before applying the $\mathrm{Lm}$ probe, the membrane was blocked with DNA from $\mathrm{Fa}$ (autoclaved for $2 \mathrm{~min}$ ) at $42^{\circ} \mathrm{C}$ for $30 \mathrm{~min}$. The ratio of the blocking DNA probe

\footnotetext{
(c) The Genetical Society of Great Britain, Heredity, 81, 659-665.
} 
DNA was $125 \times$. Hybridization was carried out at $42^{\circ} \mathrm{C}$ overnight. After post-hybridization washes at $86 \%$ stringency ( $6 \mathrm{~m}$ urea, $0.4 \%$ SDS in $0.5 \times \mathrm{SSC}$ ) for the pTa71 probe and $97 \%$ stringency $(6 \mathrm{M}$ urea, $0.4 \%$ SDS in $0.1 \times \mathrm{SSC}$ ) for the $L m$ total DNA probe, hybridization was visualized on film by enzyme-catalysed emission of light by oxidation of luminol to give the luminographs.

\section{Results}

\section{In situ hybridization}

GISH was carried out on $\mathrm{Fa}\left(\mathrm{FpFpFgFgFg} \mathrm{Fg}_{1}\right)$ and on the $L p \times F a$ hybrid. The results are shown in Fig. 1 for a representative single cell of $F a$ probed in three different ways: (i) total genomic DNA from $\mathrm{Lm}$ (Fig. 1a); (ii) combined probe of total $\mathrm{Lm}$ DNA + pTa71 (Fig. 1b); (iii) total genomic DNA of $F p$ (Fig. 1c); and for $L p \times F a$ probed with total $L p$ (Fig. 1d).

It is clear from Fig. 1a that the $L m$ probe crosshybridizes with all 14 chromosomes of $F p$, which are identified by the $F p$ probe shown in Fig. 1c; and the way in which this hybridization occurs is a feature of particular interest. The hybridization pattern reveals a number of localized 'GISH bands' that serve as markers for individual $F p$ chromosomes. When these GISH bands are taken in conjunction with the pTa71 probe (Fig. 1b), the marking of chromosomes is even clearer and discriminates at least four out of seven of the $F p$ chromosome pairs. Pair 1 has an interstitial rDNA site; pair 2 is a metacentric with two GISH bands, symmetrically located in a median position in each arm; pair 3 shows one wide band located adjacent to the centromere, plus a smaller band in the other arm; and pair 4 has a single band at the centromere.

Apart from cross-hybridizing to all $F p$ chromosomes, the $L m$ genomic DNA acts as a sequencespecific probe and detects the interstitial pTa71 site in $F p$ and the terminal pTa71 sites in Fg (Fig. 1a). There are six rDNA loci (three pairs) in the $L m$ genome (Thomas et al., 1996), and the enrichment of this particular DNA fraction in the total genomic probe accounts for the detection of these sequencespecific sites in $\mathrm{Fa}$. In general, the $L \mathrm{~m}$ probe shows limited affinity with $\mathrm{Fg}$ and, apart from the terminal rDNA sites, it only hybridizes to the centromere region of a single pair of chromosomes (Fig. 1a, large arrows). Evidently, there is much closer homology between the $L m$ and $F p$ genomes than between $\mathrm{Lm}$ and $\mathrm{Fg}$.
The same kinds and the same pattern of GISH bands on $F p$ are also revealed by probing the $L p \times F a$ hybrid with total genomic DNA from $L p$ (Fig. 1d).

\section{Southern hybridization}

DNA from three Festuca species, $F a, F p$ and $F g$, digested with BamHI, show different levels of hybridization with total genomic DNA of $\mathrm{Lm}$, corresponding to different levels of homology (Fig. 2). Fp clearly shows the highest level of homology with $\mathrm{Lm}$, as indicated by a strong signal, whereas $F g$ shows very low hybridization. $\mathrm{Fa}$ is intermediate in intensity between $F p$ and $F g$. In addition to these general patterns, there is a clearly identifiable common band shared by $L m, F a$ and $F p$ of approximately $2.5 \mathrm{~kb}$, which is not visible in $\mathrm{Fg}$.

The results for the pTa71 probe are shown in the luminograph in Fig. 3. The DNA of the four species was digested with three different restriction enzymes, Eco RI, DraI and BamHI. Because $F a$ is a natural hybrid between $F p$ and $F g$, it would be expected to contain bands specific to its progenitor species. The BamHI digest is the most informative, and it demonstrates that the $F a$ bands derive from either $F p$ or $F g$. It also shows that, for estimating relationships, the correspondence between dense and faint bands is as important as that between the dense bands. The difference in intensity of corresponding bands between $F g$ and $F a$ is caused by a difference in copy number. It is known from FISH (Thomas et al., 1997; this work) that $F g$ had lost three or four rDNA sites, whereas $F p$ retains them unchanged in $\mathrm{Fa}$. A comparison of the similarities between $L m$ and $F p$, and $L m$ and $F g$, shows that $L m$ shares more bands with $F p$ than it does with $F g$, in keeping with the relationships revealed by GISH and by the genomic Southern hybridizations.

\section{Discussion}

The application of GISH and Southern genomic hybridization gives strong visual evidence for high levels of homology between the genomes of $\mathrm{Lm}$ and $F p . F p$ is a constituent genome of $F a$, and this result clearly indicates that the $F p$ genome is the principal basis of the close relationship between $L m$ and $F a$. The closeness between Lolium and Festuca in the section Bovinae, which includes $F p$ and $F a$, has been reported widely (Lehvaslaiho et al., 1987; Xu \& Sleper, 1994; Bulinska-Rodomska \& Lester, 1998) and has led to calls to realign these species within a single genus (e.g. Darbyshire, 1993). 
In this work, segmental regions on the $F p$ chromosomes showed an especially high affinity with a total genomic DNA $\mathrm{Lm}$ probe. These 'GISH-banding' markers offer a new dimension to chromosome discrimination in plants. What is the genetic signifi- cance of these bands? The way in which the total genomic DNA of $\mathrm{Lm}$ detects the rDNA in $F p$ suggests an explanation for their origin. Localized regions of the $F p$ genome appear to be represented as multiples in $\mathrm{Lm}$, and this could provide a possible
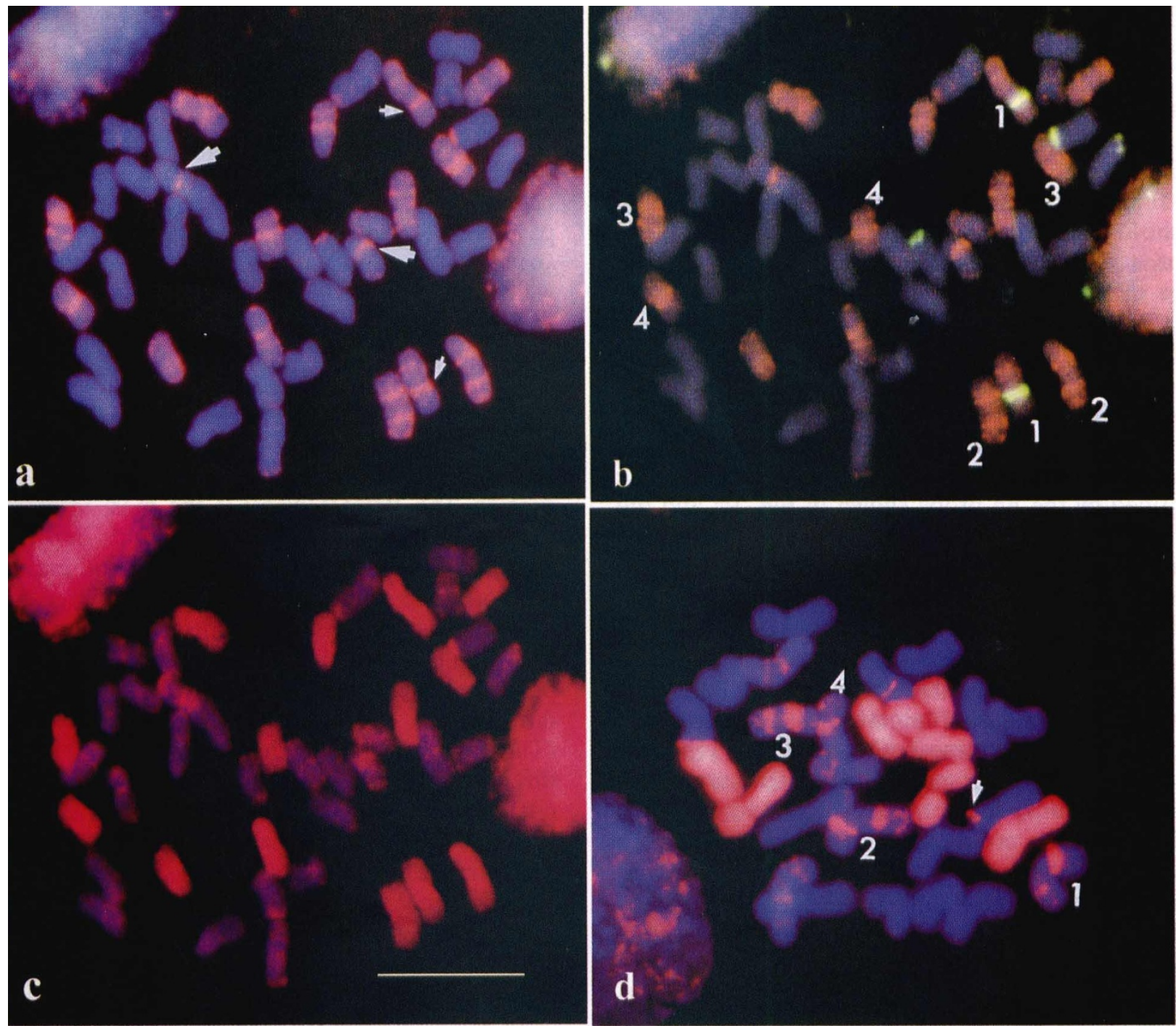

Fig. 1 Metaphase chromosomes from a single root meristem cell of the allohexaploid Festuca arundinacea (Fa, $2 n=6 x=42$ ), probed in various ways (a, b and c), and (d) from the tetraploid hybrid of Lolium perenne ( $L p) \times F$. arundinacea $(2 n=4 x=28)$. (a) The cell was probed with rhodamine-labelled total genomic DNA of $L$. multiflorum $(\mathrm{Lm})$ and shows cross-hybridization to all 14 chromosomes of the $F$. pratensis $(F p)$ component of the $F a$ genome. A number of distinctive GISH bands are present on a number of chromosome pairs of $F p$ (e.g. the pair with the small arrows) and also on one pair from the $F$. glaucescens $(F g$ ) set (large arrows) of $F a$. (b) The same cell double-probed with the genomic DNA of $L m$ and the pTa71 rDNA probe (green). The combination of probes permits us to recognize the chromosome pairs labelled 1, 2, 3 and 4 of $F p$. Two interstitial rDNA sites are visualized on $F p$ and three terminal sites on $F g$. These sites correspond to the bands produced by the $L m$ genomic probe in (a). (c) The rhodamine-labelled probe made from $F p$ total genomic DNA establishes the identity of the $F p$ chromosomes. (d) Total genomic DNA of $L p$ labels the seven $L p$ chromosomes (red) in this hybrid cell and also gives an identical pattern of cross-hybridization and chromosome-specific GISH bands on the $F p$ chromosomes to that produced by the genomic DNA of $L m$. The numbers in (d) correspond to those in (b), and the arrow identifies a terminal NOR site on one of the Fg chromosomes. 
mechanism for genome evolution in the Festucal Lolium complex. Another possibility is that some of them are repetitive sequences, common to $L m$ and Fp (Perez-Vincente et al., 1992), which are thought to be dispersed in $L m$ but to be present in $F p$ in a localized tandem repeat arrangement. However, other larger genomic rearrangements known to occur in the evolution of repetitive DNA sequences (Flavell, 1980) cannot be excluded.

The close structure between the $L m$ and $F p$ genomes explains the high levels of homoeologous meiotic pairing and recombination that takes place between them (Humphreys \& Thorogood, 1993) but, notwithstanding their similarities, the two species are sufficiently divergent in their dispersed repeats to be discriminated readily by GISH. Previous evidence supporting a closer degree of homology between $L m$ and $F p$ than between $L m$ and $F g$ came

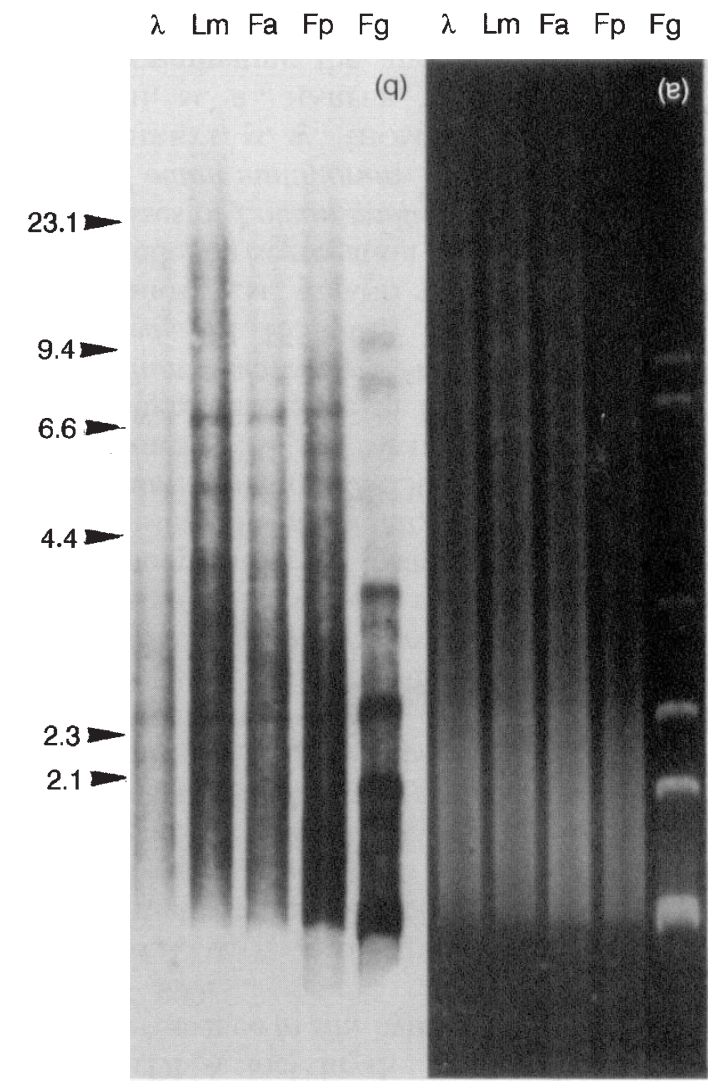

Fig. 2 Genomic Southern hybridization using the ECL method. (a) Ethidium bromide-stained gels showing Bam HI digests of Lolium multiflorum ( $\mathrm{Lm}), F$ arundinacea $(F a), F$. pratensis $(F p)$ and $F$. glaucescens $(F g), 1 \mu$ g per lane. (b) Luminograph showing hybridization of a genomic $L m$ probe to the same digests (a) of $L m, F a, F p$ and $F g$; ECL detection 35-min. The DNA size maker is given in $\mathrm{kb}$.

(C) The Genetical Society of Great Britain, Heredity, 81, 659-665. from recombination studies (Humphreys \& Ghesquière, 1994). The studies revealed the products of meiotic recombination involving all combinations of $\mathrm{Lm}, \mathrm{Fp}$ and $\mathrm{Fg}$ in plants derived from $\mathrm{Lm} \times \mathrm{Fa}$ hybrids. However, in backcross populations between $L m \times(L m \times F a)$, the frequency of recombinants involving $\mathrm{Lm} \times \mathrm{Fp}$ was twice that found between the $\mathrm{Lm}$ and $\mathrm{Fg}$ chromosomes. It now seems possible that regions of particularly high homology, represented here as the GISH bands, could actually provide the physical basis for the high levels of recombination that occur in the hybrids between $L m$ and $F p$ species.

The rDNA gene cluster has been used widely in phylogenetics (Schlötterer, 1998), and the restriction analysis carried out here further extends our knowledge of these particular regions and reveals the close evolutionary links between the rDNAs of $\mathrm{Lm}$ and $F p$. This result agrees with earlier work by Charmet et al. (1997), using the internal transcribed spacer (ITS), which also indicated these close relationships, as well as showing that Lolium is of more recent origin than Festuca. It is known, however, that rapid sequence changes are a characteristic feature

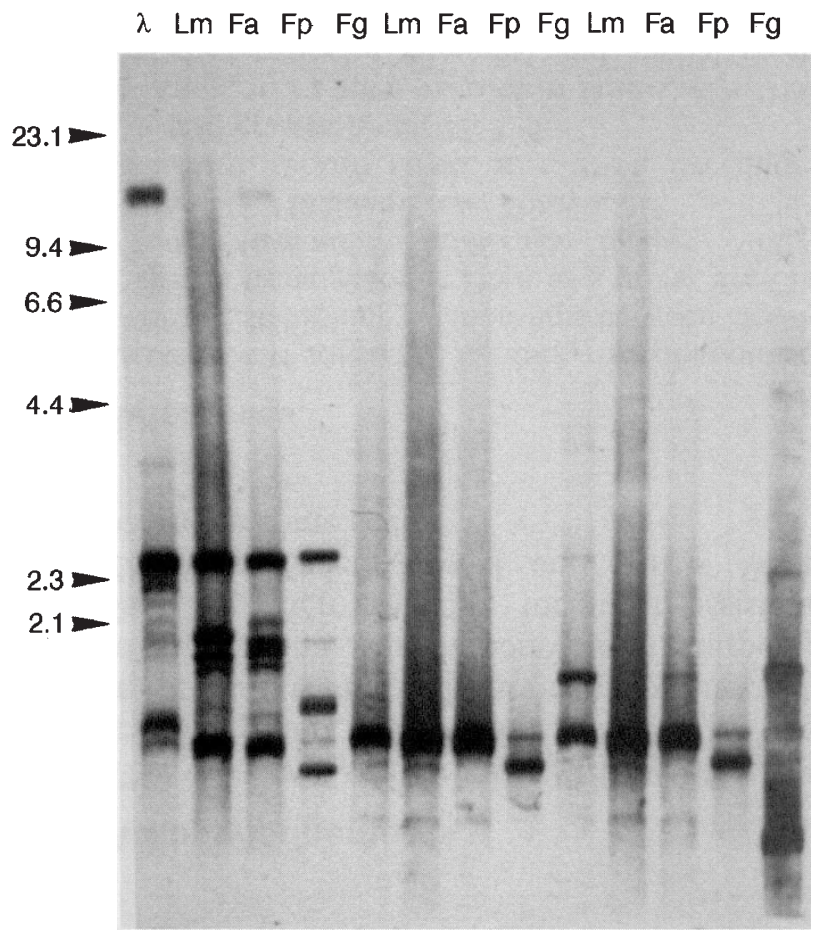

Fig. 3 Southern blot hybridization patterns of rDNA pTa71 to $L$. multiflorum $(L m), F$ arundinacea $(F a), F$. pratensis $(F p)$ and $F$. glaucescens $(F g), 1 \mu \mathrm{g}$ per lane. Digests 2-5 with EcoRI, 6-9 DraI, 10-13 BamHI, track 1 for $\lambda$ marker. ECL detection 5 min. The DNA size maker is given in $\mathrm{kb}$. 
of rDNA sites in plants (Flavell, 1986; Rogers \& Bendich, 1987). Such changes are generally attributed to the intergenic spacer (IGS) region, as was clearly demonstrated in Hordeum species (Molnar et al., 1989). Furthermore, the rDNA loci can also change their map location (Dubcovsky \& Dvorák, 1995 ) or may be lost under selection pressure resulting from adverse conditions (Fukui et al., 1994). Nevertheless, our restriction analysis shows that the $F a$ progenitors, $F p$ and $F g$, have maintained their rDNA sequences in a highly conserved form, despite the fact that a number of the $F g$ original sites are no longer represented in $F a$ (Thomas et al., 1997). This kind of analysis could be useful for studying the origins of other allopolyploids, such as $F$. mairei $(2 n=4 x=28)$ and $F$. atlantigena $(2 n=8 x=56)$.

There are practical implications that follow from our understanding of these species relationships. It has been shown, for example, that drought-tolerant genotypes among the recombinants from $\mathrm{Lm} \times \mathrm{Fa}$ backcrosses carry segments of $F p$ introgressed into the Lm genome (Humphreys \& Pašakinskienè, 1996). The molecular basis of the close homology between $L m$ and $F p$, which is demonstrated by this work, indicates that it can be expected to produce valuable and viable new germplasm through introgression breeding.

\section{Acknowledgements}

This work was supported by a Royal Society/NATO fellowship and a fellowship provided by The Ministry of Culture and Education in Iceland. I.P. wishes to thank Zina Adriulaitiene, John Harper and Ian Sant for their valuable technical assistance, and Zbigniew Zwierzykowski and Lukas Wolters for providing some seeds.

\section{References}

ANAMTHAWAT-JÓNSSON, K. AND HESLOP-HARRISON, J. S. 1996. Establishing relationships between closely related species using genomic DNA as a probe. In: Clapp, J. P. (eds) Methods in Molecular Biology, Vol. 50, pp. 209-225. Humana Press, Totowa, NJ.

BREESE, E. L. AND LEWIS, E. J. 1984. Breeding versatile hybrid grasses. Span, 27, 3-5.

BUCKNER, R. C., HILL, H. D. AND BURNS, B. S. 1961. Some characteristics of perennial and annual ryegrass $\times$ tall fescue hybrids and of the amphyploid progenies of annual ryegrass $\times$ tall fescue. Crop $S c i$., 1, 75-80.

BULINSKA-RODOMSKA, Z. AND LESTER, R. N. 1998. Intergeneric relationships of Lolium, Festuca and Vulpia (Poaceae) and their phylogeny. Plant Syst. Evol., 159, 217-227.
Charmet, G., RAvel, c. AND BAlfourier, F. 1997. Phylogenetic analysis in the Lolium-Festuca complex using molecular markers and ITS rDNA. Theor. Appl. Genet., 94, 1038-1046.

CREMADES, P. AND BEAN, E. W. 1975. Inflorescence development and seed production in Lolium spp. $\times$ Festuca pratensis tetraploid hybrids. J. Agric. Sci., 85, 301-307.

DARBYSHIRE, s. J. 1993. Realignment of Festuca subgenus Schedonorus with genus Lolium (Poaceae). Novon, 3, 239-243.

DUBCOVSKY, J. AND DVORÁk, J. 1995. Ribosomal RNA multigene loci: nomads of the Triticeae genomes. Genetics, 140, 1367-1377.

DOYLE, J. J. AND DOYLE, J. L. 1990. Isolation of plant DNA from fresh tissue. Focus, 12, 13-15.

FLAVELL, R. B. 1980. The molecular characterization of plant chromosomal DNA sequences. Annu. Rev. Plant Physiol., 3I, 569-596.

FLAVELL, R. B. 1986. The structure and control of expression of ribosomal RNA genes. Oxford Surveys Plant Mol. Biol., 3, 251-274.

FUKUI, K., OHMIDO, N. AND KHUSH, G. S. 1994. Variability in rDNA loci in the genus Oryza detected through fluorescence in situ hybridization. Theor. Appl. Genet., 8, 839-899.

GERLACH, w. L. AND BEDBROOK, J. R. 1979. Cloning and characterization of ribosomal RNA genes from wheat and barley. Nucl. Acids Res., 7, 1869-1885.

HUMPHREYS, M. W. 1989. The controlled introgression of Festuca arundinacea genes into Lolium multiflorum. Euphytica, 42, 105-116.

HUMPHREYS, M. W. AND GHESQUiÈre, M. 1994. Assessing success in gene transfer between Lolium multiflorum and Festuca arundinacea. Euphytica, 77, 283-289.

HUMPHREYS, M. W. AND PAŠAKINSKIENĖ, I. 1996. Chromosome painting to locate genes for drought resistance transferred from Festuca arundinacea into Lolium multiflorum. Heredity, 77, 530-534.

HUMPHREYS, M. W. AND THOMAS, H. 1993. Improved drought resistance in introgression lines derived from Lolium multiflorum $\times$ Festuca arundinacea hybrids. Plant Breed., 111, 155-161.

HUMPHREYS, M. W. AND THOROGOOD, D. 1993. Disturbed Mendelian segregation at isozyme marker loci in backcrosses of Lolium multiflorum $\times$ Festuca pratensis hybrids to Lolium multiflorum. Euphytica, 66, 11-18.

HUMPHREYS, M. W., THOMAS, H. M., MORGAN, W. G., MEREDITH, M. R., HARPER, J. A., THOMAS, H. ET AL. 1995. Discriminating the ancestral progenitors of hexaploid Festuca arundinacea using genomic in situ hybridization. Heredity, 75, 171-174.

Lehvaslaiho, H., Saura, A. AND LOKKI, J. 1987. Chloroplast DNA variation in the grass tribe Festucacea. Theor. Appl. Genet., 74, 298-302.

MALIK, C. P. AND THOMAS, P. T. 1966. Karyotypic studies in some Lolium and Festuca species. Caryologia, 19, 167-196.

(c) The Genetical Society of Great Britain, Heredity, 81, 659-665. 
MOLNAR, S. J., GUPTA, P. K., FEDAK, G. AND WHEATCROFT, R. 1989. Ribosomal DNA repeat unit polymorphism in 25 Hordeum species. Theor. Appl. Genet., 78, 387-392.

PAŠAKINSKIENE, I., ANAMTHAWAT-JÓNSSON, K., HUMPHREYS, M. W. AND JONES, R. N. 1997. Novel diploids following chromosome elimination and somatic recombination in Lolium multiflorum $\times$ Festuca arundinacea hybrids. Heredity, 78, 464-469.

PEREZ-VINCENTE, R., PETRIS, L., OSUSKY, M., POTRYKUS, I. AND SPANGENBERG, G. 1992. Molecular and cytogenetic characterization of repetitive DNA sequences from Lolium and Festuca: applications in the analysis of Festulolium hybrids. Theor. Appl. Genet., 84, 145-154.

ROGERS, S. O. AND BENDICH, A. J. 1987. Ribosomal RNA genes in plants: variability in copy number and in the intergenic spacer. Plant Mol. Biol., 9, 509-520.

SCHLÖTTERER, C. 1998. Ribosomal DNA probes and primers. In: Karp, A., Isaac, G. I. and Ingram, D. S. (eds) Molecular Tools for Screening Biodiversity, pp. 267-276. Chapman \& Hall, London.

THOMAS, H. AND hUMPHREYS, M. O. 1991. Progress and potential of inter-specific hybrids of Lolium and Festuca. Agric. Sci., 117, 1-8.
THOMAS, H. M., MORGAN, W. G., MEREDITH, M. R., HUMPHREYS, M. W., THOMAS, H. AND LEGGET, J. M. 1994. Identification of parental and recombined chromosomes in derivatives of Lolium multiflorum and Festuca pratensis by genomic in situ hybridization. Theor. Appl. Genet., 88, 909-913.

THOMAS, H. M., HARPER, J. A., MEREDITH, M. R., MORGAN, W. G., THOMAS, I. D., TIMMIS, E. AND KING, I. P. 1996. Comparison of ribosomal DNA sites in Lolium species by fluorescence in situ hybridization. Chrom. Res., 4, 486-490.

THOMAS, H. M., HARPER, J. A., MEREDITH, M. R., MORGAN, W. G. AND KING, I. P. 1997. Physical mapping of ribosomal DNA sites in Festuca arundinacea and related species by in situ hybridization. Genome, 40, 406-410.

XU, w. W. AND SLEPER, D. A. 1994. Phylogeny of tall fescue related species using RFLPs. Theor. Appl. Genet., 88, $685-690$.

ZWIERZYKOWSKI, Z., JOKS, W. AND NAGONOWSKA, B. 1994. Potential of tetraploid Festulolium (Festuca pratensis $\times$ L. multiflorum). In: Rognli, O. A., Solberg, E. and Schjelderup, I. (eds) Breeding Fodder Crops for Marginal Conditions, pp. 299-300. Kluwer, Dordrecht. 